\title{
PUBLIC RELATIONS IN PUBLIC ADMINISTRATION: ROLE AND MANAGEMENT, IN A SOCIO-POLITICAL MARKETING CONTEXT
}

\author{
Dorian Pocovnicu \\ Interdisciplinary Doctoral School in Marketing, "Transilvania” University of Braşov \\ dorianpocovnicu@yahoo.com
}

\begin{abstract}
Many agree that PR and marketing are at their best when used together, when it comes to local public administration institutions there is the need for both an individual and symbiotic approach of the two. Taking into consideration that public interest organizations act within public space, $P R$ represents a public communication strategy. Thus they present the role of generating a climate and state of social normality and, especially in democratic societies, $P R$ plays the part of generator of communication flows between public institutions, citizens and stakeholders. In a social-political marketing context, envisaged as an aggregate of processes, with a multiple purpose, the generator which is $P R$ must unfold coherently for each of the processes. It is our purpose in this paper to depict the PR role and management in the case of one local public administration institution (Bacau Prefect Institution), in a socio-political marketing context.
\end{abstract}

\section{Keywords}

public relations; communication process; participative democracy; citizens

\section{JEL Classification}

M31; M38

\section{Introduction}

Public relations in public administration must be approached from a broader perspective, as the endeavor set into motion by an organization with the explicit purpose of establishing sympathetic relations with the audience (Dagenais, 1999). From another perspective, as a strategic instrument of communication, public relations refer to all the measures of institutional communication initiated by an organization, designed to promote all its accomplishments and an improved image of the institution from the point of view of its target audiences, both internal and external (elected representatives and those belonging to government organizations, union representatives, media groups, general public) (Lamizet \& Silem, 1997).

The most important characteristics of public relations are (Thomlison, 2000): deliberation - the PR activity presents an intentional character, it is the result of specific research and targets informing, influencing and obtaining a response from the audience; planning - the resources of any organization are limited, both human and financial alike, and also from the point of view of equipment and time; performance the efficiency of the PR team and its results are directly linked to the performance of the client organization. Ignoring or endangering the public interests by an organization burdens the results of PR strategies; bilateral communication - PR is grounded in taking over the information from within the environment in which the organization operates, diffusing new information and following their feedback; public interest - the motivation of PR activity is to satisfy the audience needs, and not 
necessarily to gain at any cost benefits for the organization; management frame - the higher the decision level regarding PR, the higher their efficiency is.

Presenting a multitude of objectives - and this is due to their complexity - , PR represents an effective technique for fading out the negative effects which might be imposed by the rhythm of current changes upon the activity of the institution, thus playing in this context an important part in encompassing how the economic activities can better adapt to different audiences or markets. The main objectives in PR, especially in the case of public institutions are: gaining the trust of the general public regarding the institution and the services provided; knowing and anticipating the expectations of the current and potential audience; stimulating the opinion leaders; engaging the audience through various activities, programmes and events; consolidating the relations with mass media, private institutions, agencies and NGOs; developing an institutional image within cultural environments; ensuring transparency for the institutions' actions towards a specific audience; complementing the weaknesses of other communication forms used by the public administration institution.

PR activity, at the level of a public institution, is oriented towards promoting public interest (Thomas, 1995). This does not mean that public relations ignore the interests of the organization. What is specific to PR is that any decision is fundamented within the importance given to respecting public interest (Steyn, 2006), among other elements. As one may easily notice, PR is essentially a communication activity. If PR refers to the management of communication between an organization and its target audience, based on public interest, the ones in charge with communication from within the public institution must constantly be in close proximity of the target audiences, they should be capable of differentiating their communication needs and they must design and convey messages according to the target audiences characteristics and follow the feedback accordingly.

\section{Role and management of PR in public administration institutions}

Should we consider that public interest organization act specifically within public space, PR could be considered a public communication strategy. PR, as a public communication strategy, generates a climate and state of social normality. Especially in democratic societies, PR plays the part of generator of communication flows between public institutions, citizens and stakeholders, so that public institutions could become acquainted with the real concerns of the citizens and that the citizens, in return, could trust the institutions and the public officers (Iacob \& Cismaru, 2003).

$\mathrm{PR}$ is highly important for public institutions because it provides the opportunities for a real communication with the audiences. They begin to show interest towards local issues, as these issues influence, directly or indirectly their interests. Nowadays no government, company or institution can function efficiently without the knowledge of their working environment, namely the workers, partners and clients. Without proper external connections, neither does democracy. The voter must be aware of how it functions, to have the proper knowledge on the decisions made for him and in his name, to be prepared in order to take fully advantage of the rights and opportunities democracy provides. PR must engage citizens in knowing their rights and obligations during any kind of government. This is required from both central and local public administration.

Organizations, including public institutions, depend on their environment due to several aspects of their activity: unfolding of action plans, identifying operational funding, the freedom to accomplish their mission etc. These organizations, in order to prosper and to fulfill their objectives, must keep track of the following aspects (Cutlip, 1994): accepting public responsibility as compelled by a more interdependent 
society - this is the source of PR thinking in management and the source of ethical behavior; to communicate, despite all obstacles, with the designated target audience, even if it is often distant and diverse - this aspect explains PR approach as a specialized function of management; to gain integration within the communities they were designed to create and to serve - this aspect defines the purpose of management and the specific praxis of PR.

Anticipating and monitoring changes, constantly measuring environment indicators, having clear and distinguishable representations, the PR department can provide the institution in due time the necessary time for planning, in order for it to be more proactive than reactive to the changes in the environment. Being efficiently connected to the environment changes requires from the institution a management of communicational and relational flows towards three large categories of audiences: internal audience, entities from close proximity and mass-media.

Internal communication is focused on the internal audience of each institution and presents as main target the task of providing information on the organization status, on its practices and policies regarding organizational development. In these recent times of fast pace in organizational change, internal communication is essential for managing the reluctance to change (better still, for the communication therapy applied to the reluctance to change) and for constructively influencing the general public behavior. Shortcomings in internal communication are directly embedded within the organizational climate, and the salient indication of an internal communication deficit is reception of information by the internal audience not through internal communication channels, but through external communication channels, especially through mass-media.

The mass-media relations from the proximity of the institution envisage primarily the relations with the local community (environment from which organizations gather their resources, especially human resources, which reflect the economic effects (Pop, 2000), social and ecologic alike) as well as the relations with the national and international environment.

Media relations are mixed with the above mentioned domains, but still they are an independent domain. Once the risk of adversity between institutions and media is overcome, the media relations are built upon the logic of partnership, of mutual advantageous benefits: the media has access to information useful for the public, and the institutions, through their PR structures, promote their specific messages. The media relations represent, for government organizations which constitute their budget from public sources, an explicit domain of the public act of information (media informs the public opinion), thus the highlight upon the prompt and complete offer of information regarding the public activity of the public institutions. No matter the domain, public information policy of the institutions may be reactive (i.e. simply reacting to information already in the media, either mass or public) or active (the institutions are prepared at any time for disseminating messages through internal and external channels of communication). An offensive policy in the media relations entails the following aspects: knowing the profile of the media; establishing the contact and maintaining an informational flow towards the media, using PR techniques; monitoring and evaluating the media messages. All of the above explain and justify the establishment of PR structures.

All of these informational and relational flows are achieved in the context of specific traits of PR, which manifest in the public institutions environment (Wilcox et.al, 1992): deliberation - informing, influencing and gaining a response from the audience; planning - any institutions' resources are limited, thus their planning must be connected to the importance of the activities; performance - the PR team efficiency and its results determine the performance of the institution in retrospect to the client; bilateral communication - gathering information from the environment in 
which the institution operates, sending out new information and follow up on the feedback; public interest - the fundamental purpose of PR is to satisfy the needs of the audience; managerial frame - the efficiency of the PR activities depend upon the quality of management.

When dealing with management, a useful tool for performing is the systemic model or public relations, where by analyzing it one can identify and order its components (Stancu, n.d.). We shall focuse only on three such elements, namely: PR structure, communication strategy and PR process.

The PR structure encompasses groups, (un)official institutions which develop and engage in public relations and/or persuasive actions. The term itself refers to public relations institutions, presidential staff, etc. A system of public relations presents a complex structure, designed to handle demands and pressures.

The second component, namely the communication strategy, is designed by the superior levels of the institutional hierarchy and covers the guidelines of the PR actions, the objectives to be met, the restrictions and the available resources. The problem of communication planning is not new, as it has been used with remarkable results in domains such as propaganda and advertising in the course of history.

The PR process is the third component of the system and represents the "hot" area of PR actions. What is being communicated by means of information actions and PR are informations and meanings, coded through different forms: language, gestures, symbols, etc.

\section{Role and management of PR in Bacau Prefect Institution - a study case synthesis}

Public Relations Service (department, office) is a structure within public administration institutions which supplies a public service of local interest, providing relations and informations useful to citizens regarding the current activity of the council, city hall, as well as other central institutions (Presidency, Parliament, Government) and represents a two-way means of communication, allowing the institution to make its intentions known and the citizens to be consulted upon public issues of special interest.

First of all, this represents the basis for a two-way communication, between citizens and local public administration, thus contributing to removing communication obstacles. Secondly, as it is a public service, the PR office relies upon the general principles of organizing and functioning of public services (Popescu, 2003): the principle of continuity - the activity must be permanent; the principle of reality - the public service must exist and must provide the results as demanded by the public authority; the principle of quantification - the result of the public service activities must be measurable, in order for a quick and correct evaluation of the modus operandi to be possible; the principle of permanent adaptability - represents the necessity for creating and developing the public service under public control, thus the personnel which supplies this service can be changed in the interest of good management; the principle of equality - it is necessary that all citizens are treated the same, discrimination is not allowed.

The Prefect Institution of Bacau County is a public institution, a legal entity with a specific budget and assets. The Prefect is the Government representative at a local level. The Prefect guarantees that the law is abided and the public order is ensured at local level, his/her activity having as basis the following principles: legality, impartiality, objectivity, transparency, free access to public information, efficiency, responsibility, specialization, citizen oriented.

Taking into consideration the administrative tasks at local level, the Prefect Institution is conditioned by the efficiency and coherence of the communication processes which 
are developed. As it is the case for other public institutions, the Prefect institution encounters several categories of audiences, where the citizenry represents the main target audience.

Analyzing the organizational structure of the institution, we have observed that it contains specialized entities for the communication process, which are responsible for developing PR strategies. Thus, the main organizational structure responsible for this aspect is the Information, Public Relations and Secretary Department, which, according to our research, presents several communication attributions equivalent to the administrative attributions designated by the national legislation for the institution. What we have also noticed is the following aspect: several communication tasks and activities which entail a specialization of the communication and PR processes, according to specific communication objectives, are not as salient as they should. Another structure is actually responsible for the PR activity, without it being named as such. The department we refer to is the Prefect Chancellery, which present attribution that denote specific organizational aspects traditionally associated to the PR responsible from within such an institution: anticipating the reactions of public opinion and feedback analysis; management guidance; establishing and implementing PR programmes and evaluating them; monitoring the press and the media relation; coordination of internal communication; event planning; identifying organizational problems and ensuring the communicational links between management and internal and external audiences.

Going beyond the formal aspects of communication, we have analyzed the website of the institution also. We have noticed that there is a keen interest for the interaction with the target audiences, namely the citizenry and mass-media. There are two such sections/menus on the website: Citizen Relation and Press Office, which bear the responsibility to gather information from the public and to send information towards the media. What was also noticeable was the interest of the institution for the quality of the relation with the citizens and for the institutional imagery that the citizen hold, thus using a permanent survey on the website from where specific information related to PR activities are extracted.

\section{Conclusions}

No matter the means and techniques used, the PR activity must be handled in direct correlation with other communication alternatives, which are at the disposal of the public institution, all of which must be envisaged strategically and framed within a global and coherent vision. In the meantime, one must take into consideration the fact that PR can only be efficient as long as the entire activity of the institution is performed at a superior qualitative level.

\section{References}

Amalancei, B-M., Manole V., Epuran Gh. (2009), Communication Et Relations Publiques Dans L'Union Européenne, Annals of Faculty of Economics, University of Oradea, Faculty of Economics, vol. 4(1), pages 542-546, May.

Cutlip, S. (1994), Effective Public Relations, Prentice-Hall.

Dagenais, B. (1999), Le métier de relationniste, Sainte-Foy, Les Presses de l’Université Laval.

Iacob, D., Cismaru, D.M. (2003), Relații publice. Eficiență prin comunicare, Editura Comunicare, București.

Lamizet, B., Silem, A. (19970, Dictionnaire encyclopédique des sciences de l'information et de la communication, Paris, Ellipses. 
Pop, D. (2000), Introducere in teoria relatiilor publice, Editura Dacia, Cluj-Napoca.

Popescu L. G. (2003), Comunicarea in administratia publica, Editura Tribuna Economica, București.

Stancu Valentin, Strategii şi tehnici de relaţii publice, suport curs, Şcoala Naţională de Studii Politice şi Administrative.

Steyn, B. (2006), Contribution of public relations to organizational strategy formulation, in Toth, E.L. (Ed.), The future of excellence in public relations and communication management. Challenges for the next generation. Mahwah, NJ: Lawrence Erlbaum.

Thomas, J.C. (1995), Public participation in public decisions: New skills and strategies for public managers, San Francisco, CA: Jossey-Bass Publishers.

Thomlison, T.D. (2000), An interpersonal primer with implications for public relations, in J.A. Ledingham \& S.D. Bruining (Eds.), Public relations as relationship management: A relational approach to public relations, Mahwah, NJ: Lawrence Erlbaum Associates.

Wilcox, Dennis L., Ault, Phillip H., Agee, Warren K. (1992), Public Relations Strategies and Tactics, Harper Collins, New York. 